\title{
Posterior Inferior Cerebellar Artery Patency after Flow-Diverting Stent Treatment
}

\author{
(D) M.R. Levitt, (D) M.S. Park, DF.C. Albuquerque, (D). Moon, DM.Y.S. Kalani, and DC.G. McDougall
}

\begin{abstract}
BACKGROUND AND PURPOSE: The rate of PICA occlusion after flow-diverting stent placement for vertebral and vertebrobasilar artery aneurysms is not known. The purpose of this study is to determine the medium-term rate of PICA patency and risk factors for occlusion after such aneurysm treatment.
\end{abstract}

MATERIALS AND METHODS: Patients were identified who had vertebral or vertebrobasilar artery aneurysms and who were treated by placing a flow-diverting stent across the PICA ostium. Demographic and procedural factors associated with stent placement were recorded. Patency of the PICA was evaluated immediately after stent placement and on follow-up angiography.

RESULTS: Thirteen patients with vertebral or vertebrobasilar artery aneurysms were treated in the study period, of whom 4 presented with subarachnoid hemorrhage. The average number of devices that spanned the PICA ostium was 1.77 (range, 1-3), with no immediate PICA occlusions. There were no postoperative strokes in the treated PICA territory, although there was 1 contralateral PICA-territory stroke of unclear etiology without clinical sequelae. In 11 patients with follow-up angiography at a mean of 10.6 months (range, $0.67-27.9$ months), the PICA patency rate remained $100 \%$.

CONCLUSIONS: Flow-diverting stent placement across the PICA ostium in the treatment of vertebral and vertebrobasilar artery aneurysms may not result in immediate or midterm PICA occlusion.

ABBREVIATION: FDS $=$ flow-diverting stent

$\mathbf{T}$ he initial studies of safety and efficacy of flow-diverting stents (FDSs), such as the Pipeline Embolization Device (Covidien, Irvine, California), for the treatment of intracranial aneurysms primarily focused on anterior circulation aneurysms. ${ }^{1}$ The application of an FDS in posterior circulation aneurysms remains controversial due to an increased risk of thrombotic and hemorrhagic complications. $^{2-4}$ The location of some vertebral and vertebrobasilar aneurysms in relation to the PICA often necessitates stent placement across the arterial ostium, theoretically risking PICA occlusion with resultant brain stem infarction. The immediate and midterm rate of branch occlusion of the PICA after FDS placement has not been described.

Received June 17, 2015; accepted after revision August 12.

From the Division of Neurological Surgery (M.R.L., F.C.A., K.M., M.Y.S.K., C.G.M.), Barrow Neurological Institute, St. Joseph's Hospital and Medical Center, Phoenix, Arizona, and Departments of Neurosurgery and Radiology (M.S.P.), University of Utah, Salt Lake City, Utah.

Please address correspondence to Felipe C. Albuquerque, MD, c/o Neuroscience Publications; Barrow Neurological Institute, St. Joseph's Hospital and Medical Center, 350 W Thomas Rd, Phoenix, AZ 85013; e-mail: Neuropub@dignityhealth.org

http://dx.doi.org/10.3174/ajnr.A4550

\section{MATERIALS AND METHODS}

This study was approved by the institutional review board of St. Joseph's Hospital and Medical Center. Review of our prospective endovascular data base was performed, and all the patients with vertebral and vertebrobasilar artery aneurysms who were treated between May 2011 and May 2015 with an FDS in which one or more devices spanned the ostium of the PICA were identified. Patient demographics, aneurysm rupture status, the number of stent devices deployed, the presence of adjunctive aneurysm coiling, antiplatelet medication reactivity testing, and the postoperative stroke rate were recorded. Initial postprocedure and follow-up angiography images were reviewed to determine the immediate and midterm PICA patency rate after FDS placement.

All but one of the patients with unruptured aneurysms were pretreated with aspirin ( $325 \mathrm{mg} /$ day) and clopidogrel (75 mg/ day) for at least 3 days before the procedure. Patients with ruptured aneurysms were treated with a single $0.125 \mathrm{mg} / \mathrm{kg}$ intraprocedural bolus of intravenous or intra-arterial abciximab after stent placement instead of dual antiplatelet pretreatment. Platelet inhibition testing was used to determine patient response to aspirin and clopidogrel. All the patients 
were maintained on antiplatelet therapy for 6 months after the index procedure, after which only aspirin $(81 \mathrm{mg} /$ day $)$ was continued.

The technique of FDS deployment has been described previously. ${ }^{5}$ All endovascular procedures were performed with the patient under general anesthesia, with neurophysiologic monitoring, and via transfemoral transarterial access. Intravenous heparin was administered to maintain an activated clotting time of at least 250 seconds. Multiple devices were placed at the discretion of the surgeon for optimal aneurysm coverage. In cases in which aneurysm coils were placed, a separate microcatheter was jailed within the aneurysm dome before FDS placement.

\section{RESULTS}

Thirteen patients (mean age, $61.3 \pm 12.4$ years) met inclusion criteria. The average aneurysm size was $9.3 \pm 4.9 \mathrm{~mm}$ in maximal dimension, and 4 of $13(30.8 \%)$ were ruptured at presentation. There were no instances of AICA-PICA complex. One of the 9 patients with an unruptured aneurysm refused clopidogrel pretreatment and only took aspirin $325 \mathrm{mg} /$ day. Platelet inhibition testing results showed that no patients had aspirin resistance and that 3 patients had clopidogrel resistance. Two of these 3 patients were switched to prasugrel (10 mg/day), and 1 patient with a history of deep venous thrombosis was maintained on preoperative warfarin ( $5 \mathrm{mg} /$ day).

In 6 patients (46\%), the aneurysm involved the PICA origin (4 in whom the PICA origin arose from the neck of the aneurysm, and 2 in whom the PICA arose from the dome of the aneurysm); in the remaining 7 patients (54\%), the PICA origin was either distinctly proximal or distal to the aneurysm. Between 1 and 3 FDS devices (mean, 1.77) were implanted. Two of 13 procedures (15.4\%) included adjuvant aneurysm coiling; both were only partially coiled because both aneurysms incorporated the PICA origin into the aneurysm dome. There were no periprocedural neurologic complications.

A review of the angiography immediately after stent deployment demonstrated PICA patency in all 13 procedures. Two patients were lost to follow-up, and the remaining 11 patients underwent follow-up angiography (mean, 10.6 months; range, 0.67-27.9 months). There were no instances of PICA occlusion or stenosis on follow-up angiography. The rate of aneurysm obliteration at follow-up was $72.7 \%$ (8/11 patients), and there was 1 case $(9.1 \%)$ of a patient with mild in-stent stenosis.

\section{DISCUSSION}

We showed that the rate of immediate and midterm patency of the PICA was high after FDS treatment of vertebral and vertebrobasilar artery aneurysms. There were no clinical sequelae from spanning the PICA ostium with one or more devices and no specific risk factors associated with PICA occlusion.

Branch occlusion after FDS placement is an uncommon occurrence. A large series of 178 aneurysms treated with FDSs found a 1.4\% (2/140) rate of branch occlusion at follow-up, in both cases posterior communicating arteries. ${ }^{6}$ Similarly, Moon et $\mathrm{al}^{7}$ reported an ophthalmic artery occlusion rate of $3.5 \%(1 / 29)$ in a series of periophthalmic artery aneurysms treated by FDS that remained clinically silent. However, other researchers reported a higher occlusion rate. Puffer et $\mathrm{al}^{8}$ studied 20 patients after FDS placement for internal carotid artery aneurysms and found that $15 \%$ of ophthalmic arteries had slow or absent flow immediately after FDS placement, with subsequent occlusion in $21 \%$ at follow-up angiography. No patients developed any clinical deficit from ophthalmologic occlusion. Another study, of 49 patients with 68 carotid aneurysms, found an overall branch occlusion rate of $4.4 \%$ ( $4 \%$ of ophthalmic and $7.1 \%$ of posterior communicating arteries) without clinical sequelae at follow-up angiography. ${ }^{9} \mathrm{~A}$ study of 11 patients with 13 carotid aneurysms in which the posterior communicating artery ostium was covered by one or more FDSs found an occlusion rate of $27 \%$, with an additional $18 \%$ with diminished flow. ${ }^{10}$ Finally, 2 reports with a combined total of 43 anterior choroidal arteries spanned by at least 1 FDS in the treatment of carotid aneurysms documented 2 branch occlusions $(4.7 \%)$ at follow-up, without clinical sequelae. ${ }^{11,12}$ No study found a significant association between branch occlusion and the number of FDS devices placed across vessel ostia.

There are limited studies of posterior circulation aneurysms treated with FDSs, only one of which (Gascou et $\mathrm{al}^{13}$ ) specifically reported the patency of the PICA. This series of 59 patients with 66 aneurysms in various locations found a $3 \%$ overall occlusion rate and $16.2 \%$ branch vessel stenosis rate at follow-up. The FDS spanned the PICA ostium in 6 patients $(9.1 \%)$; none of these PICAs were occluded on immediate or follow-up angiography, though stenosis was seen in 2 of 6 patients at the 12-month followup. In contrast, we did not observe any PICA stenosis in the 11 patients with follow-up angiography, though our average follow-up was only 10.6 months.

Neurologic deficit is rare after branch occlusion by FDS placement. ${ }^{13-15}$ Two patients in the series from Gascou et $\mathrm{al}^{13}$ had infarction after coverage of the middle cerebral artery perforators and the anterior division of the middle cerebral artery bifurcation, respectively. Three patients with basilar tip aneurysms (in which the FDS was placed from the P1 segment to the midbasilar artery) had brain stem perforator-related infarction among a series of 32 posterior circulation aneurysms treated by FDS. ${ }^{15}$ Finally, a patient with a complex A1 segment aneurysm treated by FDS awoke from the procedure with perforator-related infarction. ${ }^{14}$ Despite acute or subacute presentation of infarction, perforator occlusion was not observed during angiography at the time of FDS placement in any of the above complications.

The low rate of PICA occlusion after FDS placement is likely related to the small size of the FDS wire diameter $(30 \mu \mathrm{m})^{16} \mathrm{com}-$ pared with the PICA diameter (mean, $1.23 \mathrm{~mm}$; range, 0.5-2.5 $\mathrm{mm}) .{ }^{17}$ The average diameter of the ophthalmic artery is reported to be between 1.75 and $2.9 \mathrm{~mm},{ }^{18,19}$ but it carries a substantially higher reported rate of immediate and long-term stenosis or occlusion after FDS placement. The higher radius of curvature at the origin of the ophthalmic artery would be expected to increase, rather than reduce, stent porosity ${ }^{16}$ compared with the relatively straight vertebral artery segment from which the PICA originates. Animal studies indicate a minimal but increased incidence of branch occlusion with lower stent porosity,${ }^{20}$ such as what might be found after FDS implantation across the PICA ostium and with multiple overlapping stents. ${ }^{21}$ However, our study and others did not find an association between the number of devices and branch 
occlusion. Animal studies indicate that the perfusion demand of tissue supplied by branch vessels that are covered by the FDS maintains branch vessel patency. ${ }^{22}$ We hypothesized that the increased volume of tissue supplied by the PICA alone demands a higher flow rate from this artery at its ostium compared with the relatively small amount of tissue perfused by the ophthalmic artery, and the rich collateral arterial network in the orbit may, in addition, reduce the demand on the ophthalmic artery. However, further animal studies are required to confirm this theory, and caution should be exercised in the presence of aneurysms that involve an AICA-PICA complex, the thrombosis of which could cause significant neurologic morbidity.

\section{CONCLUSIONS}

In this small series, FDS placement across the PICA ostium in the treatment of vertebral and vertebrobasilar artery aneurysms did not result in immediate or midterm PICA occlusion.

Disclosures: Cameron McDougall—UNRELATED: Consultancy: Covidien, MicroVention Inc.

\section{REFERENCES}

1. Becske T, Kallmes DF, Saatci I, et al. Pipeline for uncoilable or failed aneurysms: results from a multicenter clinical trial. Radiology 2013; 267:858-68 CrossRef Medline

2. Siddiqui AH, Abla AA, Kan P, et al. Panacea or problem: flow diverters in the treatment of symptomatic large or giant fusiform vertebrobasilar aneurysms. J Neurosurg 2012;116:1258-66 CrossRef Medline

3. Ertl L, Holtmannspotter M, Patzig M, et al. Use of flow-diverting devices in fusiform vertebrobasilar giant aneurysms: a report on periprocedural course and long-term follow-up. AJNR Am J Neuroradiol 2014;35:1346-52 CrossRef Medline

4. Albuquerque FC, Park MS, Abla AA, et al. A reappraisal of the Pipeline embolization device for the treatment of posterior circulation aneurysms. J Neurointerv Surg 2015;7:641-45 CrossRef Medline

5. Nelson PK, Lylyk P, Szikora I, et al. The Pipeline embolization device for the intracranial treatment of aneurysms trial. AJNR Am J Neuroradiol 2011;32:34-40 CrossRef Medline

6. Yu SC, Kwok CK, Cheng PW, et al. Intracranial aneurysms: midterm outcome of Pipeline embolization device-a prospective study in 143 patients with 178 aneurysms. Radiology 2012;265:893-901 CrossRef Medline

7. Moon K, Albuquerque FC, Ducruet AF, et al. Treatment of ophthalmic segment carotid aneurysms using the Pipeline embolization device: clinical and angiographic follow-up. Neurol Res 2014;36: 344-50 CrossRef Medline
8. Puffer RC, Kallmes DF, Cloft HJ, et al. Patency of the ophthalmic artery after flow diversion treatment of paraclinoid aneurysms. J Neurosurg 2012;116:892-96 CrossRef Medline

9. Vedantam A, Rao VY, Shaltoni HM, et al. Incidence and clinical implications of carotid branch occlusion following treatment of internal carotid artery aneurysms with the Pipeline embolization device. Neurosurgery 2015;76:173-78; discussion 178 CrossRef Medline

10. Brinjikji W, Lanzino G, Cloft HJ, et al. Patency of the posterior communicating artery after flow diversion treatment of internal carotid artery aneurysms. Clin Neurol Neurosurg 2014;120:84-88 CrossRef Medline

11. Raz E, Shapiro M, Becske T, et al. Anterior choroidal artery patency and clinical follow-up after coverage with the Pipeline embolization device. AJNR Am J Neuroradiol 2015;36:937-42 CrossRef Medline

12. Brinjikji W, Kallmes DF, Cloft HJ, et al. Patency of the anterior choroidal artery after flow-diversion treatment of internal carotid artery aneurysms. AJNR Am J Neuroradiol 2015;36:537-41 CrossRef Medline

13. Gascou G, Lobotesis K, Brunel H, et al. Extra-aneurysmal flow modification following Pipeline embolization device implantation: focus on regional branches, perforators, and the parent vessel. AJNR Am J Neuroradiol 2015;36:725-31 CrossRef Medline

14. van Rooij WJ, Sluzewski M. Perforator infarction after placement of a Pipeline flow-diverting stent for an unruptured A1 aneurysm. AJNR Am J Neuroradiol 2010;31:E43-E44 CrossRef Medline

15. Phillips TJ, Wenderoth JD, Phatouros CC, et al. Safety of the Pipeline embolization device in treatment of posterior circulation aneurysms. AJNR Am J Neuroradiol 2012;33:1225-31 CrossRef Medline

16. Shapiro M, Raz E, Becske T, et al. Variable porosity of the Pipeline embolization device in straight and curved vessels: a guide for optimal deployment strategy. AJNR Am J Neuroradiol 2014;35:727-33 CrossRef Medline

17. Pai BS, Varma RG, Kulkarni RN, et al. Microsurgical anatomy of the posterior circulation. Neurol India 2007;55:31-41 CrossRef Medline

18. Erdogmus S, Govsa F. Anatomic features of the intracranial and intracanalicular portions of ophthalmic artery: for the surgical procedures. Neurosurg Rev 2006;29:213-18 CrossRef Medline

19. Govsa F, Erturk M, Kayalioglu G, et al. Neuro-arterial relations in the region of the optic canal. Surg Radiol Anat 1999;21:329-35 CrossRef Medline

20. Hong B, Wang K, Huang Q, et al. Effects of metal coverage rate of flow diversion device on neointimal growth at side branch ostium and stented artery: an animal experiment in rabbit abdominal aorta. Neuroradiology 2012;54:849-55 CrossRef Medline

21. Dai D, Ding YH, Kadirvel R, et al. Patency of branches after coverage with multiple telescoping flow-diverter devices: an in vivo study in rabbits. AJNR Am J Neuroradiol 2012;33:171-74 CrossRef Medline

22. Kallmes DF, Ding YH, Dai D, et al. A new endoluminal, flow-disrupting device for treatment of saccular aneurysms. Stroke 2007;38: 2346-52 Medline 